\title{
A Study of the Learners' Metaphorical Perceptions of Literary Genres
}

\author{
Öğgrencilerin Edebi Türler ile İlgili Metaforik Algıları Üzerine Bir Çalışma
}

\begin{abstract}
Merve EKİ** Aynur KESEN MUTLU **

Abstract: The perception of language has been studied from various aspects to date, whereas how students perceive literature remains today a less researched area. The quantity of qualitative research concerning the perception of literature needs to be increased. The present study aims to fill this gap by exploring students' perception in respect to the concept of literary genres through the use of metaphor as they reflect the way we perceive the world and shape our professional ideas and attitudes. In addition, the study investigates whether there is a difference in perceptions between junior and senior learners in regard to their perception of literary genres. The study participants were 58 first and 43 fourth grade ELL students enrolled in İstanbul University, Turkey. The data were collected through the use of semi structured interviews, multiple-choice questionnaire and metaphor elicitation papers. The metaphors of literary genres exhibited both the positive and negative perceptions of the learners. The Ring, Narnia, detergent concentrate, veritaserum ('iksir' in Turkish) and pomegranate were some of the unique positive metaphors of the learners. Some metaphors seem to be negative such as Pandora's Box, dark hole, ivy and labyrinth.
\end{abstract}

Keywords: Perception of Literature, Literary Genres, Metaphorical Perceptions, Conceptual Metaphors

Öz: Dilin algılanması ile ilgili farklı açılardan çalışmalar yapılıış olmasına rağmen edebiyatın algılanışı daha az araştırma yapılmış bir alandır. Bu nedenle edebiyatın algılanışı ile ilgili daha fazla niteliksel araştırmanın yapılması gerekmektedir. Bu çalışma, öğrencilerin edebi türler ile ilgili algılarını kullandıkları metaforik kavramlar ile araştırmayı amaçlamıştır. Çünkü metaforlar dünyayı algılama biçimimizi yansıtır ve profesyonel fikirlerimizi ve tutumlarımızı biçimlendirir. Ayrıca bu çalışma birinci sınıf ve dördüncü sınıf öğrencilerinin edebi türlere bakış açılarındaki farkı araştırmaktadır. Bu çalışmaya, İstanbul Üniversitesi İngiliz Dili ve Edebiyatı bölümü birinci sınıf öğrencilerinden 58, dördüncü sınıf öğrencilerinden 43 kişi katılmıştır. Çalışmanın verileri öğrencilerle yapılan görüşme, çoktan seçmeli anket ve metaforlarını yazmaları için hazırlanan form aracılığıyla elde edilmiştir. Edebi türler ile ilgili metaforlar, öğrencilerin olumlu ve olumsuz bakış açılarını yansıtmaktadır. Yüzük, Narnia, yoğunlaştırılmış deterjan, iksir ve nar öğrencilerin oluşturdukları özgün ve olumlu metaforlardan bir kısmıdır. Pandora'nın kutusu, kara delik, sarmaşık ve labirent gibi bazı metaforların olumsuz olduğu görülmektedir.

Anahtar sözcükler: Edebiyatın Algılanışı, Edebi Türler, Metaforik Algılar, Kavramsal Metaforlar

\footnotetext{
*Ph.D. Candidate, İstanbul Aydın Üniversitesi, Sosyal Bilimler Enstitüsü, İngiliz Dili ve Edebiyatı Bölümü, İstanbul. merveekiz5@gmail.com

** Yrd. Doç. Dr., Medipol Üniversitesi, İstanbul. aynur.kesen@gmail.com
} 


\section{Metaphor as a Reflective Tool}

Metaphors can be powerful reflective tools that help people to reflect their common everyday experiences in a new light. They have the ability to reach a deeper level of knowing. They are particularly vivid and powerful because they arouse emotions in us. Consequently today, metaphors form an essential part of studies investigating beliefs and values. Lakoff and Johnson (1980) state that "metaphors not only make our thoughts more vivid and interesting but they actually structure our perceptions and understanding". When a metaphor is employed, the schema is transported from its customary realm into a new realm. In Lakoff and Johnson's opinion (1980) metaphors help us in comprehending experiences and understanding what goes on around us. The reasons vary as to why metaphors are a powerful reflective tool. In Kliebart's opinion (1982) metaphors are "a fundamental vehicle of human thought". In addition, their expressibility, compactness, and vividness make metaphors better conceptualized (Ortony \& Fainsilber 1989; Nikitina \& Furuoka 2008). In the view of the philosophy of constructivism "knowledge is a constructed version of the world and each individual makes sense of his/her own world on the basis of his/her own personal experiments, constructs, and hypotheses" (Kelly 1955). Bredeson (qtd. in Balc1 1999) extends the importance of metaphors in unearthing beliefs by emphasizing that metaphors help people in generating ideas, concepts and theories for describing, examining, and understanding phenomena in education.

\section{Metaphor in Related Studies}

Metaphors and metaphoric analysis as analytic and descriptive tools have recently been used in educational research. Elements of education have been analysed with the help of metaphors to understand the perceptions of individuals and to solve the problems they experience. In the field of education, researchers have started to see metaphor as a powerful tool that can be used to understand and to explore the current state of educational practices. A brief search in the international educational literature reveals the following research interests which employed metaphorical analysis; educational change, school improvement and educational reform (Zachariah 1985; Schlechty \& Joslin 1986; Cole 1990) reported in Lieberman (1986), teacher education (Hanson 1984; Berliner 1990; Bullough 1991; Marchant 1992; Dana \& Pitts 1993), school quality, staff development and organizational culture (Steinhoff \& Owens 1989), and classroom management (Weinstein 1994), organizational, classroom, student, and learning level (Bibik 1997; Karbach 1997; Dooley 1998), metaphors in student, school, and institutional writing (Godina 1995; Rosenfeld \& Bhusan 1995; Elford 1996; Herbst 1997; Johnson-Sheehan 1997). A review of literature in Turkey indicates the following studies used metaphorical analysis, the metaphorical perceptions of EFL learners (Ahkemoğlu 2011), Turkish EFL learner's Metaphors with Respect to English Language Course books (Kesen 2010), Metaphorical Images of School (Balc1 1999) and Metaphorical Conceptualizations of an Adult EFL Learner: Where Old Concepts Are Impregnable (Parvaresh 2008).

\section{The Studies on the Perceptions of Literature and Literary Genres}

Students' perception of language has been studied from various aspects to date whereas students' perception of literature remains a less researched subject. There are some survey studies in this area and they are important being remarkable attempts to examine students' attitudes toward literature. Fan-ping Tseng summarizes these studies (Hirvela \& Boyle 1988; Akyel \& Yalçın 1990; Davis et al. 1992) in his survey by pointing out that Davis, Gorell, Kline, and Hsieh (1992) investigated university students' attitudes toward the study of literature in a foreign language as well as the factors affecting their opinions about literature in general. The 
participants in their study were undergraduates enrolled in introduction to literature courses in departments of French and Spanish. Analysis of the participants' responses to a questionnaire showed that most of them held positive attitudes toward foreign language literature. Moreover, two factors were found to be significantly related to their attitudes toward literature study, namely, the amount of leisure reading done in the foreign language, and the preferred learning styles, such as being given opportunities to express their personal opinions, to look for the underlying meaning of the text, and to read about people and experiences different from their own. In other words, students' attitude toward literature may be influenced not only by their own reading habits but also by the teachers' instructional methods. Hirvela and Boyle (1988) and Akyel and Yalçın (1990) were concerned with learners in ESL/EFL settings. Hirvela and Boyle (1988) surveyed ESL working adult learners' attitudes towards the literature courses offered in a part-time degree program in a university. The aim of their survey was to determine which literary genres were most favoured or feared by the students and which aspects of literature gave the students most trouble. The results of their survey showed that the students most enjoyed 'prose fiction' (i.e. novel and short story) and they feared 'poetry' the most; in addition, the students found the 'interpretation of theme' most difficult when studying literature, followed by some language-related aspects of literature (e.g. vocabulary in non-modern texts). These results are valuable for literature teachers as, with students' preferences and perceived difficulty of literature in mind, teachers can provide students with more suitable literary texts and more crucial or immediate help. Akyel and Yalçın (1990) investigated EFL senior high school students' reactions to the specific contributions of prose fiction, drama, and poetry, in developing language and literary competence. Their survey results showed that the students regarded the 'novel' as the most effective literary form in helping them to develop their linguistic skills and cultural awareness, and 'drama' as the most effective in helping them improve oral expressions. Moreover, the students considered 'poetry' and 'short stories' as not having much effect upon their language skills. 'Poetry' in particular was thought to make the least significant contribution to their language skills development. The survey also revealed a link between the students' language proficiency and their attitudes towards literature, those who rated their English proficiency as high appreciated the literary texts selected, while, in contrast, those who rated their proficiency as average found the literary texts boring and difficult. The study of Tseng (2010) aimed to document a teacher-researcher's teaching of literature and to explore students' perceptions of the literary works introduced and their attitudes toward different literary genres. His survey results showed that among the four genres presented, most students preferred prose fiction (i.e. novels and short stories) and plays to poems. Students usually favoured the works which they had the opportunity to appreciate performances of in other media. It showed the plot summaries of novels and plays could motivate fewer than half of the participants to read the original texts, most of which were Shakespeare's tragedies. Students particularly like to read contemporary literature rather than classic literature, and such works as movie novels, realistic fiction, fantasies, and mysteries are their favourites. The results of his study also shed some light on what literature to teach in EFL classes. In general, many EFL students are interested in prose fiction. Thus, short stories and novels, especially movie tie-in novels, can be first introduced to students since those works might easily arouse students' interest. On the other hand, poems or plays can be introduced later in EFL classes and should be presented with some well-designed activities. These four studies give us an idea about the students' attitudes toward literature of different populations. For instance, ESL/EFL students generally seem to appreciate 'novels' most and 'poetry' the least, as indicated by Hirvela and Boyle (1988) and Akyel and Yalçın (1990). In addition to these studies, Arıkan's (2005) study 
reveals that prospective teachers view literature courses as an important part of their pre-service teacher education while recommending minor changes in the literature curriculum so that these courses become more effective. Nevertheless, there is still the need to investigate EFL learners' perceptions or attitudes toward different literary genres. For example, although Hirvela and Boyle (1988) had investigated students' preferences among different literary genres, the participants were working adult ESL learners, whose literary tastes may not be similar to those of adolescent EFL students in normal educational settings. For another, Akyel and Yalçın (1990), though involving EFL high school students, surveyed their reactions to literature as means of developing their language skills. Lastly, Tseng (2010) surveyed the EFL students' preferences in literature. There still remains a gap in understanding the students' perception of literary genres. It is possible that students have different perceptions of 'literature as an area of knowledge' or "literature as pleasure" (escaping from daily problems, and filling leisure moments) or "literature as self-discovery" (understanding themselves through literature). To accept or deny this possibility, a further survey of students' perceptions of literature seems to be a reasonable solution. With the aim of understanding the students' perceptions of literary genres from a different perspective, a survey concerning the metaphoric perceptions of literary genres by students will be a reasonable solution.

\section{Research Questions}

In this study, the answers to the following research questions were investigated:

1. What are the conceptual metaphors of first and fourth grade students enrolled in the ELL Department in regard to their perception of novel?

2. What are the conceptual metaphors of first and fourth grade students enrolled in the ELL Department in regard to their perception of short stories?

3. What are the conceptual metaphors of first and fourth grade students enrolled in the ELL Department in regard to their perception of poetry?

4. What are the conceptual metaphors of the first and fourth grade students enrolled in the ELL Department in regard to their perception of drama?

5. Which literary genres do ELL learners mostly have difficulty in reading/analysing?

6. What are the preferences of ELL learners in respect to the types of literary genres?

\section{Research Method}

\section{Design of the Study}

The present study adopted a mixed method design to determine the conceptual metaphors of literature learners. Qualitative methods "allow the researcher the flexibility to probe initial participant responses- that is, to ask why or how". The qualitative data were collected through the metaphor elicitation method and in interviews. The quantitative data was collected via a multiple choice questionnaire with two questions. The reason for using three methods of data collection was to achieve the triangulation of data. The metaphors generated by learners were described, categorized, compared and analysed by means of content analysis since the data format was textual not numerical. The data collected through multiple choice questionnaires was numerical. The SPSS statistical program was utilized to see whether there was any significant difference between the two groups (first and fourth grade students at the English Language and Literature Department of istanbul University). The participants of the study were all volunteers. After obtaining the approval of the Dean of the Faculty, all the first and fourth 
grade students were informed of the study and told to let the researchers know if they wanted to participate in the study. A session with the participants was held before the data collection procedure started. All the participants were informed about the aim of the study and detail of the data collection procedures.

\section{Participants}

The participants for the present study were 101 English Language and Literature students enrolled at İstanbul University. 58 of these were first grade students of the English Language and Literature Department. 43 of them were fourth grade students of the English Language and Literature Department. The literary background of the first and fourth grade students was different from each other. The first grade students were just starting out in studying literature and attending the courses: Introduction to English Literature, Mythology in English Literature, Applied Textual Studies 1 and Fantasy Fiction, whereas the fourth grade students attended most of the courses at İstanbul University ELL Department such as: Introduction to English Literature, Mythology in English Literature, Applied Textual Studies 1, Fantasy Fiction, Outlines of English Literature, Textual Analysis, Applied Textual Studies 2, Composition, Critical Approaches to English Literature, English Theatre, Popular English Literature, Selected Works in English Literature, $16^{\text {th }}$ Century English Literature, Author and His/her Works, Milton and his Time, $18^{\text {th }}$ Century English Literature, Composition, Short Story, Literature and Performing Arts.

\section{Data Collection Tools}

In this study qualitative and quantitative data collection tools and procedures were used. The instruments utilized in the study were the metaphor elicitation sheet, semi-structured interviews and a multiple choice questionnaire.

\section{Data Analysis}

The data obtained was analysed and interpreted using the content analysis method. The reason for utilizing this method was that "concepts and themes that are not noticeable using the descriptive approach may be seen by using the content analysis" (Yıldırım \& Şimşek 2005). In addition, in content analysis, the researcher focuses on coding and categorizing the data, which makes this technique rich (Sternler 2001). In addition to the researcher conducting the present study, the data were read by two other instructors to check their relevance for this study. Following this procedure, all the metaphors created by the participants were classified under various themes as categories. Unlike many studies on metaphors, the themes in the present study were based upon the reasons that the participants stated in their choice of metaphors in regard to their perceptions of literary genres. The steps in which the analysis and interpretation of the metaphors were carried out can be summarized as follows:

1. The metaphors that both first and fourth grade students of the English Language and Literature Department created and wrote in the metaphor elicitation sheet were listed alongside with the entailments that participants wrote.

2. The students' interview data was analysed to see how the students elaborated on the reason for creating a specific metaphor for the concept of literary genres. The analysis of the interview was carried out to strengthen the entailments that students wrote in their metaphor elicitation sheet. The entailments acquired from the students' interviews were added to the list of metaphors prepared by the researcher.

3. The metaphors which had common characteristics in relation to the concept of literary 
genres were grouped under the same theme at the category development level.

4. The themes of the study were created on the basis of the entailments obtained from the four instruments used in the study (metaphor elicitation sheet and interview). In other words, the conceptual categories such as illumination, pleasure and discovery etc. were created on the basis of the participants' reasons for choosing a specific metaphor.

5. Two instructors (familiar with studies on metaphors) were given the list of themes and related metaphors prepared by the researcher and they were asked to decide whether the metaphors and the categories in which they appeared matched or not, in order to provide reliability in this study. There were some disagreements between the researcher and the two instructors on some of the metaphors and the categories in which they should appear. The interviews were processed once more for those metaphors, and the names of the themes were changed.

6. The metaphors that the first grade and the fourth grade students at the English Language and Literature Department created were first analysed separately.

7. All of themes and the related metaphors were analysed in detail. The metaphors created by the participants were analysed on the basis of the metaphor elicitation sheet and interview data. The metaphors and the explanations of the metaphors were read and they were grouped under themes in terms of their function, such as giving pleasure, depth of meaning and nutrition. Each researcher worked on grouping the themes and the themes created by two researchers were compared to see if there were any mismatches. Representative quotations of the participants were used in elaborating on the participants' metaphors for the concept of literary genres.

8. In the multiple choice questionnaire part, all the choices of the first grade and the fourth grade ELL participants were analysed first separately. The aim was to find the most difficult genre and the most preferred genre of the participants and to understand the reasons and the similarities/discrepancies of the first grade and the fourth grade ELL participants' choices.

\section{Findings and Discussion}

The metaphors developed by the participants were categorized into themes to reveal the ELL learners' perception of literary genres. Table 2 displays the first three most frequently used metaphors developed by both first grade and fourth grade students of the ELL department for the concept of novel.

Table 2 displays the first three most frequently used metaphors by both first grade and fourth grade students of the ELL department for the concept of novel.

\section{The Three Most Frequently Used Metaphors for the Concept of the Novel Developed by both first grade and fourth grade students of the ELL Department}

The metaphors "ocean" (n:7;1 5,47\%), “world”' (n:5; 11,05\%) and "life” (n:3; 6,63\%) have the highest frequency among all the other metaphors developed by first grade students of ELL department participants. That is to say, 7 out of the 44 participants believe that the novel is an ocean. 11,05 percent of the participants are of the opinion that a novel can best be described as a "world". The reason why the participants associate world with novel may be due to the discovery of a new world which has some similarities with and differences from the world they inhabit. In addition, these participants may see the novel as the key to a new world of unknown experiences. We see the metaphor "life", as the metaphor with the third highest frequency. For the first grade participants using this metaphor, the novel is best represented as the 
representative of reality and real lives, just as the lives of the characters may have similarities with the readers' lives.

When we look at the most frequently used metaphors developed by fourth grade students of ELL department participants, we see two common metaphors "life" and "world". The metaphors "life" (n:8; 20\%), "mirror" (n:8; 20\%) and "world" (n:2; 5\%) are those with the highest frequency. 20 percent of participants see the novel as "life". In addition, 8 of the participants are of the opinion that the novel is a "mirror". These two metaphors may indicate that in reading novels, the learners find themselves, their previous life experiences and the society they live in reflected.

\section{The Three Most Frequently Used Metaphors for the Concept of Poetry Developed by both of the ELL Department}

The metaphors "puzzle" (n:2; 5,4\%), and "world" (n:2; 5,4\%) have the highest frequency among all the metaphors used by first grade ELL department participants. The other metaphors are used only by one student. That is to say 2 out of 37 participants believe that poetry is a puzzle, as analysing a poem is a challenging activity like solving a puzzle. As in the metaphor "puzzle", 5,4 percent of the participants are of the opinion that poetry can be best described as a "woman". The reason why participants associate poetry with woman may be because the language of both women and poetry is similar as they do not say what they mean directly.

When we look at the most frequently used metaphors developed by fourth grade student of ELL department participants, we see only one common metaphor "puzzle" (n:3; 7,5\%) shared between first grade and fourth grade students of the ELL department. It is an interesting result that poetry is a challenging activity like a puzzle for both first grade and fourth grade students amongst ELL participants. The learners' attitude towards poetry does not seem to change much over the years. The metaphors "puzzle" (n:3; 7,5\%), "song” (n:3;7,5 \%) and "feeling” (n:3;7,5 $\%)$ are those with the highest frequency. 7,5 percent of the participants regard poetry as a "puzzle". In addition, three of the participants are of the opinion that poetry is a "song" and three of the participants are of the opinion that poetry is "feeling". These three metaphors may indicate that poetry influences our feelings like a song but it is difficult to solve like a puzzle for the participants.

\section{The Three Most Frequently Used Metaphors Developed for the Concept Drama by both first grade and fourth grade student participants of the ELL Department}

The metaphors "life" (n:3; 8,34\%), "mirror" (n:3; 8,34\%), and "reflection" (n:3; 8,34\%) have the highest frequency amongst all the metaphors developed by first grade student participants of the ELL department. That is to say, 3 out of 36 participants believe that drama is life, as the participants find their previous experiences in drama. As in the metaphor "life", 8,34 percent of participants are of the opinion that drama can be best described as a "mirror" and a "reflection". The reason why participants associate drama with a mirror or a reflection may be due to drama's reflection of the readers' inner conflicts or lives.

When we look at the most frequently used metaphors developed by fourth grade student participants from the ELL department, we find only one common metaphor, "mirror" (n:5; 12,2 \%) between first grade and fourth grade student participants of the ELL department. It is an interesting result that drama is a mirror reflecting the inner world and lives for both first grade and fourth grade student participants from the ELL department. The learners' thoughts about drama do not seem to change much throughout the years. The metaphors "mirror" (n:5; 12,2 \%), "world" (n:3; 7,32\%) and "way" (n:3; 7,32\%) are those with the highest frequency. 12,2 
percent of the participants see drama as a "mirror". In addition, 3 of the participants are of the opinion that drama is "world" and the metaphor, "way" has the same frequency as the metaphor "world". These metaphors may indicate that drama reflects society, our inner worlds, and the drama is itself a world in which we have new experiences.

The Most Frequently Used Metaphors Developed for the Concept of Short Story by both first grade and fourth grade student participants of the ELL Department

In this study, the metaphors "candy" (n:3; 8,58\%) and "puzzle" (n:2; 5,78\%) have the highest frequency amongst all the metaphors developed by first grade student participants of the ELL department participants. That is to say 3 out of 35 participants believe that short story is candy as drama evokes the participants' positive feelings and give them pleasure. 5,72 percent of participants are of the opinion that the short story can be best described as a "puzzle". The reason why the participants associate the short story with a puzzle is because a short story provides less about the characters and events than in a novel and so is more difficult to analyse with less details and so is like a puzzle, difficult to solve.

When we look at the metaphors developed by fourth grade student participants of the ELL department, we see that all of the metaphors share the same frequency.

In the following part the commonalities and differences are analysed in detail.

The Common Metaphors for the Literary Genres (under the same theme) Developed by first grade and fourth grade student participants of the ELL Department

7 themes and 11 metaphors are developed by both first grade and fourth grade student participants of the ELL department for the concept of literary genres. We see the metaphors "ocean", "forest" and "sea" under the theme of depth of knowledge. As we see, regardless of their major, the participants believe that literary genres are deep. That is to say, both for first grade and fourth grade student participants of the ELL department, literary genres give you more as you go more deeply into them. We may conclude that the participants like to go deeper in their minds through these literary genres. Secondly, we see the metaphor, "life" under the theme of reality. We can conclude that the experiences and feelings they have with literary genres are as real as life for them, as real as they can find everything in life. The other common metaphors are "mirror" and "reflection" under the theme of reflection. We may come to the conclusion that the literary genres reflect the learners' inner thoughts, feelings and the society they live in. The other metaphor which is used by both the first grade and fourth grade student participants of the ELL department is "chocolate", under the theme of pleasure. By using this metaphor, participants may refer to the pleasure they have provided by the literary genres. The metaphor "dream" is also used under the theme of imagination by both first and fourth grade participants. We can conclude that the literary genres improve their imagination. The last metaphor both grades of participant use is "puzzle" under the theme of challenge. By using this metaphor, the participants may refer to the difficulty they have in understanding and analysing literary genres.

\section{Common Metaphors of the Literary Genres (under different themes) Developed by first grade and fourth grade student participants of the ELL Department}

Two common metaphors appear under different themes. One of the common metaphors we find is "world". When the metaphor "world" is used by the first grade participants, it refers to "reflection". However, when the concept is used by the fourth grade participants, it shifts into discovery. The second common metaphor is "life". The meaning carried by the word changes 
for the two different themes, as when it is used by the first grade participants, it means reality, but, on the other hand, when the same metaphor is used by the fourth grade participants, it means discovery. The last common metaphor "ocean" is used under the theme of depth of meaning by all of the students using that metaphor in this study, except for one student from the fourth grade who used it under the theme of discovery.

\section{Analysis of the Positive and Negative Metaphors for the Novel given by First and Fourth Grade Student Participants of ELL}

\section{The Positive Metaphors for a Novel}

The common themes of positive metaphors are "depth of meaning", "discovery", "reality", "illumination", "beauty", "imagination", "nutrition" and "self-journey". Some of the positive metaphors of the first and fourth grade students are under different themes, such the themes of the first grade students: "pleasure", "fun", "power", "guidance”, "quantity" and "emotion" and the themes of the fourth grade students such as: "reflection", "cure/treatment", "nutrition", "art" and "subjectivity". The various metaphors the participants use reflect the positive influence of novel in its different aspects.

\section{The negative metaphors for the Novel given by First and Fourth Grade Student Participants of ELL}

The common theme of both grade students' negative metaphors is "challenge". The metaphor "labyrinth" was developed under the theme of challenge by a first grade participant. The metaphors "dark hall" and "danger" was developed by the fourth grade students. Further, the negative metaphor "Pandora's box" was developed under the theme of "depth of meaning" by a fourth grade participant. Except for the metaphor "Pandora's box", in this study the theme "depth of meaning" includes positive metaphors.

\section{Analysis of the Positive and Negative Metaphors for Poetry of the First and Fourth Grade Student Participants of the ELL Department}

The Positive Metaphors for Poetry of the First and Fourth Grade Student Participants of the ELL Department

The common themes of positive metaphors are: "depth of meaning", "beauty", "art", "illumination", "self-journey", "emotion”, "nutrition”, "reflection”, "form” and "reality". Some of the positive metaphors of the first and fourth grade students are under different themes, such the theme of the first grade students, "fun", and the theme of the fourth grade students such as "provider of understanding life/people". The different aspects of the positive influence of poetry can be seen from the metaphors the participants use.

\section{The Negative Metaphors for Poetry of the First and Fourth Grade Student Participants of the ELL Department}

The common theme of the first and fourth grade students' negative metaphors is "challenge". In addition, the negative metaphors: "cabbage", "headache", and "lie" are developed under the theme of "annoyance/dislike" by first grade participants. The metaphor "puzzle" is commonly used by both grades of students. 
Analysis of the Positive and Negative Metaphors of the $1^{\text {st }}$ and $4^{\text {th }}$ Graders of ELL for Drama

\section{The Positive Metaphors for Drama of the First and Fourth Grade Student Participants of the ELL Department}

The common themes of positive metaphors are: "pleasure", "reflection", "depth of meaning", "discovery", "art", "reality", "fun" "power" and "form". Some of the positive metaphors of both grades of students are under different themes, such as the themes of the first grade students: "beauty", "liberation", "power/control", "imagination", "value", and the themes of the fourth grade students such as: "superiority", "cure/treatment", "vitality", "guidance” and "provider of understanding (for) people". These metaphors reflect the positive influence of drama on the students. On the other hand, the negative metaphors of the first and fourth grade participants and for drama are: "effort", "discussion board" and "challenge". The common theme of the first and fourth grade participants' negative metaphors is "challenge".

\section{The Positive Metaphors for Short Story of the First and Fourth Grade Student Participants of the ELL Department}

Some of the positive metaphors of both grade students for short story are: "chocolate", "second half time football match", "lyric notes", "tequila”, "candy", "concentrate detergent", "gin" and "low fat latte". The common themes of positive metaphors are "pleasure", "time", "discovery" and "reality". Some of the positive metaphors of the first and fourth grade students are under different themes, such the themes of the first grade students: "nutrition", "source of knowledge", "illumination" and the themes of the fourth grade students such as: "fun", "power", "selfjourney", "guidance", "provider of understanding", "value" and "form". These metaphors reflect the positive influence of short story on these students.

The Negative Metaphors for Short Story of the First and Fourth Grade Student Participants of the ELL Department

Some of the negative metaphors of the first and fourth grade student participants of the ELL for the short story are: "labyrinth", "puzzle", "closed box", "empty frame" and "midget". The themes of the first and fourth grade students' negative metaphors are common, such as "challenge" and "limitedness".

Analysis of the Most Difficult Genre in Reading and Analysis for the First Grade participants of the ELL Department

\section{The Choices of the First Grade students for the most Difficult Genre in Reading/Analysis}

In this study, 49 of the 58 participants choose poetry (n:49; 85,75\%). The survey results of Hirvela and Boyle (1988) showed that students feared 'poetry' the most. Similarly, the study of Tseng (2010) showed that among the four genres presented, most students preferred prose fiction (i.e. novels and short stories) and plays to poems. In addition, the research findings of Akyel and Yalçin (1990) indicated that the students considered 'poetry' and 'short stories' as not having much effect upon their language skills. 'Poetry' in particular was thought to make the least significant contribution to the development of their language skills.

The other choices of the participants are for the novel (n: 3; 5,25\%), for drama (n: 2;3,5\%) and for the short story (n: 3; 5,25\%). Poetry is remarkably mostly chosen as the most difficult genre in reading/analysing by the first grade ELL participants. The reasons are the abstract language of poems, metaphors, images and devices such as ambiguity, symbolism, irony, and 
other stylistic elements of poetic diction that leaves a poem open to multiple interpretations.

Analysis of the Most Preferred Genre for First Grade Student Participants of the ELL Department

\section{The Choices of the First Grade Student Participants of the ELL Department for the most Preferred Genre}

In this study, 44 of the 58 participants choose the novel (n: 44; 75,68\%). The other choices of the participants were poetry (n: $3 ; 5,16 \%$ ), drama (n: $1 ; 1,72 \%$ ) and the short story (n: 10 ; $17,2 \%)$. The novel was remarkably mostly chosen as the most preferred genre to read by the first grade ELL participants. The choices of the participants might be due to the long pleasure a novel provides, the escaping of the reader of the novel from his/her daily life, discovering a new world, new experiences and characters in the novel. The survey results of Akyel and Yalçın (1990) showed that students regarded the 'novel' as the most effective literary form in helping them develop their linguistic skills and cultural awareness. In addition, the research findings of Hirvela and Boyle (1988) and Tseng (2010) showed that the students enjoyed 'prose fiction' the most.

Analysis of the Most Difficult Genre in Reading and Analysis for the Fourth Grade Participants of ELL

The choices of the fourth Grade participants for the most difficult genre for reading/analysis

In this study, 27 of the 42 participants choose poetry (n: 27; 62,92\%) as the most difficult genre for reading/analysing. The other choices made by the participants were the novel (n: 5; 11,65\%), drama (n: $5 ; 11,65 \%$ ) and the short story (n: 5; 11,65\%). Poetry was chosen as the most difficult genre in reading/analysing by the first and fourth grade of ELL participants. The choices of the participants might be due to any metaphors, images and the devices such as ambiguity, symbolism, irony, and other stylistic elements of poetic diction that leaves a poem open to multiple interpretations.

Analysis of the Most Preferred Genre for the Fourth Grade Students of the ELL Department

\section{The choices of the fourth grade students for the most preferred genre to read}

This survey shows the most preferred genre to read is the novel for the fourth grade participants of the ELL department. 22 of the 43 participants choose the novel (n: 22;51,26\%). The second most frequent choice was the short story (n: 10;23,3\%). The other choices of the participants were poetry (n: 4;9,32\%) and drama (n: 7;16,31\%). The novel was chosen as the most preferred genre to read by both the first and fourth grade participants. The choice made by the majority of participants may be due to the long pleasure a novel gives, the escaping of the novel reader from his/her daily life, discovering a new world, new experiences and characters in the novel.

Analysis of Choice for the most Difficult Genre in Reading and Analysis of the First and Fourth Grade Student Participants of the ELL Department

In this study, both the first and the fourth grade participants chose poetry as the most difficult genre in reading/analysis. The negative attitudes towards poetry do not change although the percentage decreases [(First grade (n: 49; 85,75\%), Fourth grade (n: 27; 62,91)]. 


\section{The Chi-Square Test 1}

When we analyse the choices of the most difficult genre in reading and analysis for the first and fourth grade participants of the ELL department, we find there is no significant difference between these two groups.

Table 1. The Chi-Square Test 1

$$
\begin{aligned}
\chi_{\text {STAT }}^{2} & =\sum_{\text {all cells }} \frac{\left(f_{o}-f_{e}\right)^{2}}{f_{e}} \\
& =\frac{(3-4.61)^{2}}{4.61}+\frac{(5-3.39)^{2}}{3.39}+\cdots+\frac{(5-3.39)^{2}}{3.39}=0.0884344
\end{aligned}
$$

fo : observed frequencies fe: expected frequencies

\section{Analysis of the most frequently Preferred Genre by the First and Fourth Grade participants of ELL}

The results of this study show both the first and the fourth grade participants prefer the novel to read. There is no change between the first and the fourth grade participants in terms of the most preferred genre, although the percentage of the participants decreases. (The first grade students (n: 44; 75,68\%), the fourth grade students (n: 22, 51,26\%)

When we analyse the choices of the most preferred genre to read for the first and the fourth grade participants of the ELL department, we find there is no significant difference between the two groups, as is recorded in Table 2.

Table 2. Chi Square Test 2

$$
\begin{aligned}
\chi_{\text {STAT }}^{2} & =\sum_{\text {all cells }} \frac{\left(f_{o}-f_{e}\right)^{2}}{f_{e}} \\
& =\frac{(44-37.90)^{2}}{37.90}+\frac{(22-28.10)^{2}}{28.10}+\cdots+\frac{(10-8.51)^{2}}{8.51}=0.0018837
\end{aligned}
$$

\section{Conclusion and Discussion}

In education in literature one of the most crucial points appears to be the learners' beliefs and attitudes toward literary genres. Each student may have a different perception of a literary genre. Therefore the learners' perceptions of a literary genre should certainly be elicited. Since metaphors have proven to be a reliable research tool in eliciting beliefs and attitudes towards literary genres, the use of metaphors in developing insights into the learners' perceptions of a literary genre should be given serious attention. As Lakoff (1980) states "metaphors not only make our thoughts more vivid and interesting but they actually structure our perceptions and understanding”.

This study attempted to investigate the conceptual metaphors of both first and fourth grade students of the English Language and Literature Department in regard to their perception of literary genres, novel, poetry, drama and short story, and it searches into the most difficult and the genre mostly preferred. In addition, this study investigates whether there is a difference in the perceptions of junior and senior students in respect to their perceptions of literary genres. It also searches into the difficulties learners claim to experience while reading the different literary genres. 
The total number of participants was 101. Of the metaphors they created, "forest" and "sea" constitute the category of "depth of meaning" which is noteworthy as one of the themes with a high frequency among the other themes. Poetry was chosen as the most difficult genre in reading/analysis by both the first and fourth grade participants. However the percentage of fourth grade ELL participants choosing poetry as the most difficult genre decreased (first grade students (n:49; 85,75\%), fourth grade students (n:27; 62,91). The novel was chosen as the most preferred genre by both first and fourth grade students. There is no change between the first and fourth grades in terms of the most preferred genre although the percentage of participants decreases [the first grade students (n:44; 75,68\%), the fourth grade students (n:22, 51,26\%)] The Chi-Square tests show that there is no significant difference between the two groups.

The metaphors of literary genres exhibited the positive and negative perceptions of the students: "The Ring”, "Narnia", "concentrate detergent", "veritaserum” and "pomegranate", were some of the unique positive metaphors of the learners. Some metaphors seem to be negative such as: "Pandora's box", "dark hole", "ivy” and "labyrinth". For this reason, it should be amongst the objectives of literature educators to elicit the learners' views of literary genres so as to help learners have positive attitudes towards literature and to eliminate any negativity caused by their previous experiences.

\section{Pedagogical Implications}

In literature teaching as in other fields, one of the most crucial points seems to be the learners' attitudes towards literary genres. Each student may have a different perception of the literary genres. The choice of literary texts, the instructors' style-method of teaching and the learners' expectations from the instructor should all be investigated before a literature course is designed so as to offer a learning environment in which students can enjoy the learning experience and consequently perform better. The first step in designing such a literature course certainly begins with establishing the learners' perceptions of the literary genres. 


\section{REFERENCES}

Ahkemoğlu H. (2011). A Study on Metaphorical Perceptions of EFL Learners Regarding Foreign Language Teacher. Published Master Thesis. Çukurova University, Adana 2011.

Akyel A. \& Yalçın E. (1990). "Literature in the EFL Class: A Study of Goal Achievement Incongruence”. ELT Journal 44/3 (1990) 174-180.

Arıkan A. (2005). “An Evaluation of Literature Component of Hacettepe University English Language Teaching Department”. Hacettepe University Journal of Education 29/1 (2005) 27-33.

Balc1 A. (1999). Metaphorical Images of School: School Perceptions of Students, Teachers and Parents from Four Selected Schools. Unpublished Master Thesis. Middle East Technical University, Ankara 1999.

Bibik J. M. (1997). Metaphors for Teaching: How Health and Physical Education Teachers Describe Their Roles. Georgetown 1997.

Bredeson P. V. (1988). “Languages of Leadership: Metaphor Making in Educational Administration”. Administrator's Handbook 32/6 (1988) 234-243.

Bullough R. V. Jr. (1991). “Exploring Personal Teaching Metaphors in Pre-Service Teacher Education”. Journal of Teacher Education 42/1 (1991) 43-51.

Dana N. F. \& Pitts J. H. (1993). "The Use of Metaphor and Reflective Coaching in the Explanation of Principal Thinking: A Case Study of Principal Change”. Educational Administration Quarterly 29/3 (1993) 23-338.

Davis J. N., Gorell L. C., Kline R. R. \& Hsieh G. (1992). "Readers and Foreign Languages: A Survey of Undergraduate Attitudes Towards the Study of Literature”. The Modern Language Journal 76/3 (1992) 320-332.

Elford C. (1996). Performance Indicators in Postsecondary Education in Alberta Analysis. Albuquerque 1996.

Godina H. (1995). Metaphorical Children's Writing in a Whole-Language Classroom. New Orleans 1995.

Herbst P. (1997). “The Number-Line Metaphor in the Discourse of a Textbook Series”. For the Learning of Mathematics 17/3 (1997) 36-45.

Hirvela A. \& Boyle J. (1988). “Literature courses and student attitudes”. ELT Journal 42/3 (1988) 179-184.

Hanson M. (1984). “Exploration of Mixed Metaphors in Educational Administration”. Research Issues in Education 23/1 (1984) 167-185.

Johnson-Sheehan R. (1997). “The Emergence of Root Metaphor in Modern Physics: Max Planck’s 'Quantum' Metaphor”. Journal of Technical Writing and Communication 27/2 (1997) 177-190.

Karbach J. (1997). Metaphors in Comments and Classrooms. Orlando 1997.

Kesen A. (2010). “Turkish EFL Learners' Metaphors with Respect to English Language Course Books”. Novitas-ROYAL (Research on Youth and Language) 4/1 (2010) 108-118.

Kelly G. A. (1955). The Psychology of Personal Constructs: A Theory of Personality. New York 1955.

Kliebart H. M. (1980). “Curriculum Theory as Metaphor”. Theory into Practice 21/1 (1980) 11-17.

Lakoff G. \& Johnson M. (1980). Metaphors We Live By. Chicago 1980.

Marchant G. J. A. (1992). “Teacher is Like a...: Using Simile Lists to Explore Personal Metaphors”. Language and Education 21/1 (1992) 377-398.

Nikitina L. \& Furuoka F. (2008). “Measuring Metaphors: A Factor Analysis of Students' Conceptions of Language Teachers”. Metaphorik.de 15/1 (2008) 161-180.

Ortony A. \& Fainsilber L. (1989). “The Role of Metaphors in Descriptions of Emotions”. Ed. Y. Wilks, Theoretical Issues in Natural Language Processing (1989) 181-184. Norwood.

Parvaresh V. (2008). "Metaphorical Conceptualisations of an Adult EFL Leaner: Where Old Concepts are Impregnable”. Novitas-ROYAL (Research on Youth and Language) 2/2 (2008) 154-161.

Steinhoff C. R. \& Owens R. G. (1987). "The Organizational Culture Assessment Inventory: Metaphorical Analysis in Educational Settings”. Journal of Educational Administration 27/3 (1987) 17-23.

Tseng F. (2010). “Introducing Literature to an EFL Classroom: Teacher's Presentations and Students' Perceptions”. Journal of Language Teaching and Research 1/1 (2010) 53-65.

Yıldırım A. \& Şimşek H. (2005). Sosyal Bilimlerde Nitel Araştırma Yöntemleri. Ankara 2005. 